\title{
Representation of Women through Print Advertisement: A Content Analysis of Advertisement of Newspaper Supplements
}

\author{
Prof. (Dr). Bandana Pandey, Vinika Garg, Manju Kataria and Sumedha Dhasmana
}

Department of Communication Management \& Technology, GJUS\&T, Hisar, Haryana.

\begin{abstract}
Portrayal of women in advertisements is an eternal part of advertising industry. Advertisement portrays women in various roles as diverse of an ordinary housewife to a completely professional career woman. Currently, there is a significant shift in the manner how women are portrayed in advertisements. The objective of this research is to scrutinize women empowerment through advertisements of leading newspaper supplements. For this study, the researchers examined advertisements of four leading newspapers of India. The researchers collected six months newspaper supplements (including Hindi and English) and adopted content analysis method for this research. The researchers conclude that the supplements of Times of India carried maximum advertisements that portrayed women in empowered form.
\end{abstract}

Keywords: Women Empowerment, Content Analysis, Advertisements, Women Advertisements, Newspaper Supplements.

\section{INTRODUCTION}

Media is said to be the fourth pillar of our society and how women are portrayed in media remains a debatable topic and an important area of research till date. Advertising being an important part of media is not untouched from similar debates. In advertisements too, women are being portrayed in varied roles. In the past, women were portrayed in stereotypical roles like that of a housewife. However, women's role has now evolved and women are often projected as empowered ones.

Empowerment can be viewed as means of creating a social environment in which one can make decisions and make choices either individually or collectively for social transformation. It strengthens the innate ability by way of acquiring knowledge, power and experience (Jacob, 2013). Empowerment can overall be defined as all those processes where women take control and ownership of their lives. Control and ownership requires an array of opportunities to choose among and this understanding of empowerment overlaps with the concept of human development when defined as a process of enlarging peoples' choices (Manuh, 2006).

Women's empowerment has five components: women's sense of self-worth; their right to have and to determine choices; their right to have access to opportunities and resources; their right to have the power to control their own lives, both within and outside the home; and their ability to influence the direction of social change to create a more just social and economic order, nationally and internationally (United Nations Population Information Network).

\section{REVIEW OF LITERATURE}

Holtzhausen, Jordaan \& North (2011) discuss the portrayal of women in South African television commercials The purpose of the study on which the article is based was to identify current role portrayals of women in advertising on selected South African television channels. A sample of 245 commercials was content analyzed to determine how women are portrayed in advertising. The findings indicate that women are most often portrayed as product users, and least often as sex objects. In terms of product categories, women featured most often in advertising for personal care items and least often in sport-related commercials. Rational advertising appeals were most commonly used in commercials featuring women. HajiMohammadi (2011) analyzed television commercials with an emphasis on gender roles to decode the main elements of a dominant discourse (preferred readings) and representation mechanisms; and the elements' relationships with ideology, hegemony and power relations in reproducing a dominant discourse. Grounded in an interdisciplinary theoretical framework of cultural studies and critical studies perspectives, the two-layer analysis is used in this paper - a 
semiotic and critical discourse analysis of television commercials with an emphasize on gender roles and ideology. The results demonstrate that the TV advertisements selected in this paper represent dominant gender relations and reproduce traditional values. Furthermore, these representations illustrate a contradiction between society and media in gender roles. In fact, dominant discourses of these advertisements indirectly raise values that reinforce traditional system of gender roles. The advertisements mainly represent gender roles of women in a traditional fashion. Therefore, there are contradictions between television advertisements and society. Consequently, the media, and television in particular, should present the real status and role of women along with an evolution of gender roles in the society.

Holtzhausen (2010) presents a content analysis of role portrayed by women in advertisements in selected South African media and found out various roles portrayed by women. The most prevalent role portrayal in magazine advertisements was that of physically decorative woman (27\%), typified as woman that symbolizes the physical ideal. The less prevalent portrayal included career woman, home maker, mother, mannequin, romantic, sex object and social being. The results also revealed that women are used as visual attention-attracting focus points in advertisements across a range of different products or service categories. The product category that most often featured women in both media was personal care products $(41 \%$ for magazine advertisements and $26 \%$ for TV advertisements).

Zimmerman (2008) discusses the sexual objectification of women in advertising. The study measures attitudes of young women to sexually objectified advertising. A survey combining elements of two previous studies (Ford, LaTour, and Lundstrom, 1991; Mittal and Lassar, 2000) was administered to 94 female undergraduates. Results show significant $(\mathrm{p}<0.001)$ changes in attitudes of young, educated women. Respondents agreed females were portrayed as sex objects in advertisements, but were less offended by these portrayals than female respondents in 1991. Results also show females' attitudes toward the advertisement have little effect on purchase intention, a highly significant change from attitudes of women in 1991.

Sethuraman, Kavita, Lansdown, Richard and Keith, and, Sullivan. (2006) examine the role of sociocultural determinants in maternal and child under nutrition in tribal and rural communities in South India. Women's lack of empowerment is believed to be an important factor in the persistent prevalence of malnutrition. The objective of the study was to explore the relationship between women's empowerment, maternal nutritional status and the nutritional status of their children aged 6 to 24 months in rural Karnataka. Structured interviews with mothers were used to collect data and anthropometric measurements were obtained for 820 mother-child pairs. Results showed that malnutrition was significantly more prevalent in the tribal community. Some degree of malnutrition was seen in $83.5 \%$ children and $72.4 \%$ mothers. Tribal families had less access to electricity, education, and health care than rural families. Child feeding practices were similar across the sample, and more than $80 \%$ of the children were still being breastfed at the time of the study. Tribal women had greater decision making capabilities and freedom of movement than rural women. The prevalence of domestic violence did not differ significantly between tribal and rural women, and it was experienced by $34 \%$ mothers in the sample. Biological variables explain the greatest variance $(15.1 \%)$ in the sample. Women's empowerment variables were significantly associated with child nutrition and $5.6 \%$ of the variance in the sample could be attributed to women's empowerment. Maternal experience of psychological abuse and sexual coercion increased the risk of malnutrition in mothers and children. The study findings suggest that better community based nutrition programs should be designed which help in reducing malnutrition.

Paterson (2004) presents a case study of Balochistan on Women's empowerment in challenging environments. He finds that women have been isolated generally from work opportunities and are expected to maintain a sense of home, community and tradition. However, in the last decade the increase in public roles for women including as Lady Health Workers and mandated seats for women in all levels of government have increased women's visibility. Women are increasingly educated and are also developing aspirations for careers and life beyond their homes. Through Mainstreaming and Gender Development, women are challenging the notion that they are custodians of tradition and culture and cannot participate in modern spheres of economics and governance without sacrificing traditional values. 
Representation of Women through Print Advertisement: A Content Analysis of Advertisement of Newspaper Supplements

\section{Hypotheses of the Research}

Three hypotheses were coined for the study:

1. Ads portraying women empowerment will be in considerable amount in the supplements as they are special editions.

2. Hindi supplements will have more of women empowerment advertisements.

3. These advertisements would be placed on front page of supplements because the OTS is high on front page.

\section{OBJECTIVES AND METHODOLOGY}

\section{Objective}

The objective of this study is to analyze women empowerment through advertisements of leading newspaper supplements.

\section{Methodology}

Content analysis may be seen as a method where the content of the message forms the basis for drawing inferences and conclusion about the content (Nachmias \& Nachmias, 1976). Content analysis is an efficient way to examine the content of the medium. The following description will make it clear how the present research has been planned. Researchers have adopted content analysis method for the study. This is a primary source of data collection. 47 supplements from each newspaper Times of India, Hindustan Times, Dainik Jagran and Dainik Bhaskar in which Times of India and Hindustan.

\section{TABUlation AND ANALYSIS}

Table1. Name of the Newspapers

\begin{tabular}{|l|l|l|l|}
\hline Supplements from Newspapers & Frequency & Valid Percent & Cumulative Percent \\
\hline Times of India & 47 & 25.0 & 25.0 \\
\hline Hindustan Times & 47 & 25.0 & 50.0 \\
\hline Dainik Jagran & 47 & 25.0 & 75.0 \\
\hline Dainik Bhaskar & 47 & 25.0 & 100.0 \\
\hline Total & 188 & 100.0 & \\
\hline
\end{tabular}

Chart1. Name of the Newspapers

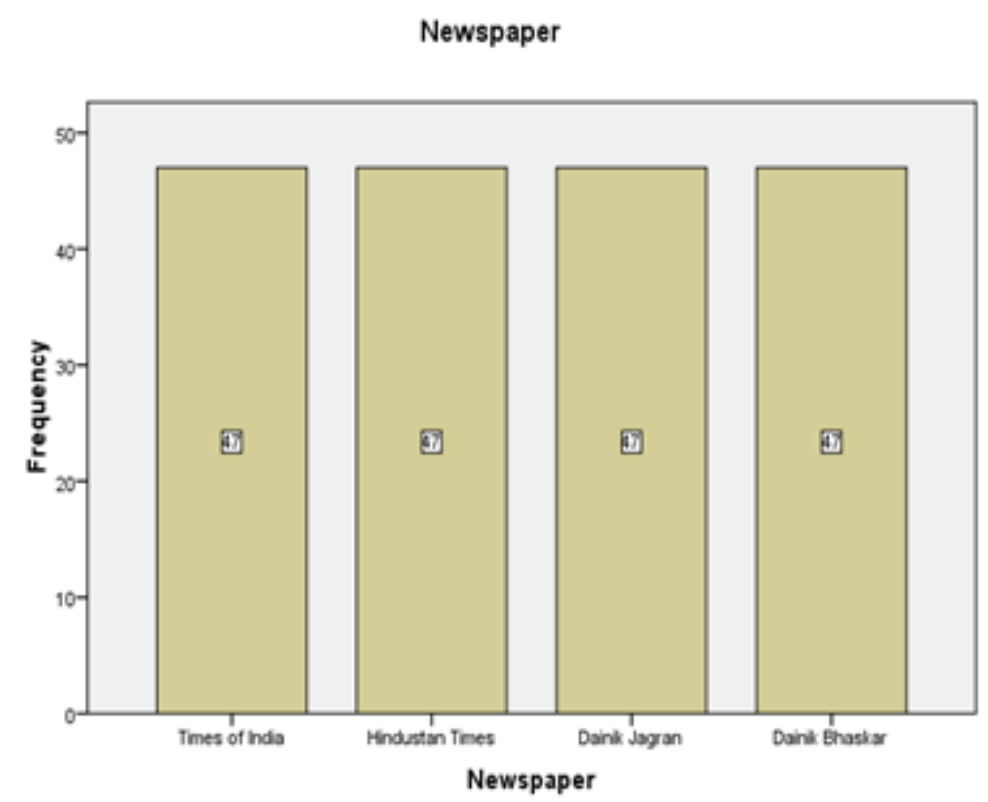

Table-1 and Chart-1 indicates that 47 supplements from each newspaper Times of India, Hindustan Times, Dainik Jagran and Dainik Bhaskar in which Times of India and Hindustan Times which are English Dailies and Dainika Jagran and Dainik Bhaskar, the Hindi Dailies respectively published during the period of 6 months were taken for the study by the researchers. 
Prof. (Dr). Bandana Pandey et al.

Table2. Name of Supplements

\begin{tabular}{|l|l|l|l|}
\hline Supplements & Frequency & Valid Percent & Cumulative Percent \\
\hline Time Ascent & 29 & 15.4 & 15.4 \\
\hline HT Magazine & 28 & 14.9 & 30.3 \\
\hline Josh & 18 & 9.6 & 39.9 \\
\hline Madhurima & 17 & 9.0 & 48.9 \\
\hline Times life & 16 & 8.5 & 57.4 \\
\hline Jhankar & 16 & 8.5 & 66.0 \\
\hline Rasrang & 16 & 8.5 & 74.5 \\
\hline Shine Job & 15 & 8.0 & 82.4 \\
\hline Navrang & 14 & 7.4 & 89.9 \\
\hline Sangini & 9 & 4.8 & 94.7 \\
\hline HT Live & 4 & 2.1 & 96.8 \\
\hline Yatra & 4 & 2.1 & 98.9 \\
\hline Education plus & 2 & 1.1 & 100.0 \\
\hline Total & 188 & 100.0 & \\
\hline
\end{tabular}

Chart2. Name of the Supplements

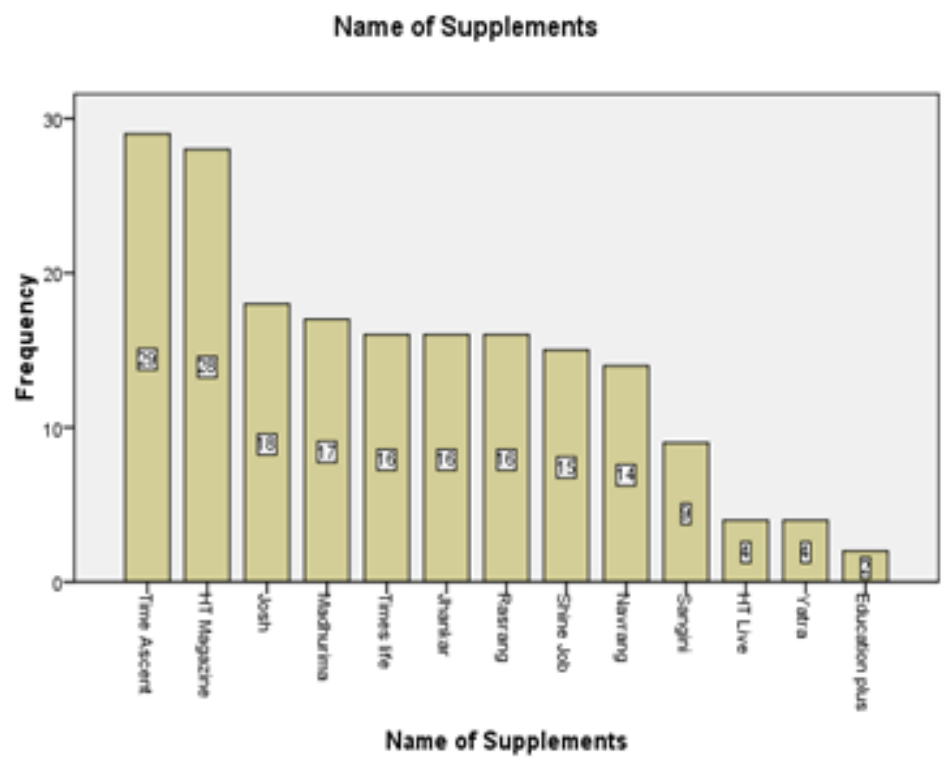

Table- 2 and Chart- 2 shows the name of supplements of each newspaper published during the period of 6 months. Total of 13 supplements -Time Ascent 29, Times Life 16, Education Plus 2 of Times Of India, HT Magazine 28, HT Live 4 and Shine Job 15 of Hindustan Times, Josh 18, Yatra 4, Sangini 9 and Jhankar 16 of Dainik Jagran, and Madhurima 17, Navrang 14 and Rasrang 16 of Dainik Bhaskar were studied by the researchers.

Table3. Total Advertisements, Women Ads and Women Empowerment Ads in the Supplements

\begin{tabular}{|l|l|l|l|}
\hline $\begin{array}{l}\text { Name } \\
\text { Supplements }\end{array}$ & $\begin{array}{l}\text { Total Number of Ads } \\
\text { in Supplements }\end{array}$ & Total Number of Women Ads & $\begin{array}{l}\text { Total Number of Women } \\
\text { Empowerment Ads }\end{array}$ \\
\hline Time Ascent & $2742(40.22 \%)$ & $139(22.24 \%)$ & $63(70.79 \%)$ \\
\hline Times Life & $100(1.47 \%)$ & $33(5.28 \%)$ & $3(3.37 \%)$ \\
\hline Education Plus & $8(0.12 \%)$ & $5(0.80 \%)$ & - \\
\hline HT Magazine & $55(0.82 \%)$ & $24(3.84 \%)$ & - \\
\hline HT Live & $5(0.07 \%)$ & - & - \\
\hline Shine Job & $3106(45.56 \%)$ & $32(5.12 \%)$ & $10(11.24 \%)$ \\
\hline Josh & $122(1.79 \%)$ & $12(1.92 \%)$ & $12(13.48 \%)$ \\
\hline Yatra & $49(0.72 \%)$ & $18(2.88 \%)$ & - \\
\hline Jhankar & $202(2.96 \%)$ & $113(18.08 \%)$ & - \\
\hline Sangini & $134(1.96 \%)$ & $90(14.4 \%)$ & - \\
\hline Madhurima & $112(1.64 \%)$ & $68(10.88 \%)$ & $1(1.12 \%)$ \\
\hline Navrang & $49(0.72 \%)$ & $19(3.04 \%)$ & - \\
\hline Rasrang & $133(1.95 \%)$ & $72(11.52 \%)$ & - \\
\hline Total & $6817(100 \%)$ & $625(100 \%)$ & $89(100 \%)$ \\
\hline
\end{tabular}


Table-3 depicts that in the period of 6 months total 6817 ads were published by 13 supplements of four dailies (Times of India, Hindustan Times, Dainik Jagran and Dainik Bhakar) out of which 625 Ads were related to women. Advertisements portraying women empowerment were 89 in number in all the supplements. This table shows that Supplements of TOI (Times life, Time Ascent) published maximum (70.79\%) ads portraying women empowerment trailed by Josh (13.48\%) (Supplement of Dainik Jagran) followed by Shine Job (11.24\%) and the least ads portraying women empowerment were published by Madhurima (1.12\%) (Supplement of Dainik Bhaskar) and other eight supplements under study didn't publish any of these Ads. Maximum number of advertisements was published by Shine Job followed by Time Ascent and Jhankar. Maximum percentage of advertisement on women was published by Time Ascent (22.24\%)and Jhankar(18.08\%) followed by Sangini(14.4\%) and Rasrang (11.52\%).

Table4. Content and Space covered by Advertisements, Women Ads and Women Empowerment Ads

\begin{tabular}{|l|l|l|l|l|}
\hline $\begin{array}{l}\text { Name of } \\
\text { Supplements }\end{array}$ & $\begin{array}{l}\text { Space of total Content } \\
\text { (in Square centimeter) }\end{array}$ & $\begin{array}{l}\text { Space of Total Ads } \\
\text { (in Square centimeter) }\end{array}$ & $\begin{array}{l}\text { Space of Women } \\
\text { Ads (in Square } \\
\text { centimeter) }\end{array}$ & $\begin{array}{l}\text { Space of Women } \\
\text { Empowerment } \\
\text { Ads (in cm. Sq.) }\end{array}$ \\
\hline Time Ascent & 395274 & 317255.75 & 40643 & 17219 \\
\hline Times Life & 106496 & 33970.5 & 13564 & 2416 \\
\hline Education Plus & 13860 & 5576 & 4447.5 & - \\
\hline HT Magazine & 192192 & 15994 & 7824 & - \\
\hline HT Live & 27289.6 & 482 & - & - \\
\hline Shine Job & 130552.5 & 86245.69 & 6591.68 & 2571.74 \\
\hline Josh & 110160 & 15338 & 2383 & 2383 \\
\hline Yatra & 24480 & 11459 & 8416 & - \\
\hline Jhankar & 97920 & 24610 & 15254 & - \\
\hline Sangini & 55080 & 20313 & 15784 & - \\
\hline Madhurima & 80784 & 16854 & 11620 & 400 \\
\hline Navrang & 83160 & 10115 & 7591 & - \\
\hline Rasrang & 109158.4 & 28795 & 20302 & - \\
\hline Total & 1426407 & 587007.9 & 154420.2 & 24989.74 \\
\hline
\end{tabular}

Table-4 shows that total space provided to total content was 142640 sq. $\mathrm{cm}$; space provided to total ads was 587007.9 sq. $\mathrm{cm}$. and 24989.74 sq.cm.space was provided to advertisements portraying women empowerment. It was seen that there is a direct relationship between the spaces provided to total content and total ads by the supplements of each newspaper and the advertisements through which empowerment of women is shown. TOI (Time Ascent and Times Life) gave content, ads as well as the ads portraying empowerment, the maximum space that is $515630 \mathrm{sq} . \mathrm{cm} ; 317255.75 \mathrm{sq}$. cm; and 19635 sq. cm. respectively followed by HT (Shine Job) \& Dainik Jagran (Josh). The least space was given by Dainik Bhaskar (Madhurima) $16854 \mathrm{sq} . \mathrm{cm}$. and $400 \mathrm{sq} . \mathrm{cm}$. to total ads and to ads representing empowered women.

Table5. Type of Ads

\begin{tabular}{|c|c|c|c|}
\hline \multirow[b]{2}{*}{ Supplements } & \multicolumn{2}{|c|}{ Type of Ads } & \multirow[b]{2}{*}{ Total } \\
\hline & Display & ay Classified & \\
\hline Time Ascent & $60(67.4 \%)$ & $3(3.4 \%)$ & $63(70.8 \%)$ \\
\hline Times Life & $3(3.4 \%)$ & $0(0 \%)$ & $3(3.4 \%)$ \\
\hline Shine Job & $6(6.7 \%)$ & $4(4.5 \%)$ & $10(11.2 \%)$ \\
\hline Josh & $9(10.1 \%)$ & $3(3.4 \%)$ & $12(13.5 \%)$ \\
\hline Madhrima & $0(0 \%)$ & $1(1.1 \%)$ & $1(1.1 \%)$ \\
\hline Total & $78(87.6 \%)$ & $11(12.4 \%)$ & $89(100 \%)$ \\
\hline
\end{tabular}

Table-5 \& Chart-3 depicts that out of 89 ads showing empowerment of women, 78 (87.6\%) were display and $11(12.4 \%)$ were display classified ads from which maximum display ads were published by Time Ascent (67.4\%) followed by Josh, Shine Job and Times Life (10.1\%), (6.7\%) and (3.4\%) respectively. Out of display classified the maximum number was published by Shine Job (4.5\%) followed by Time Ascent and Josh which published the same percentage of display classified (3.4\%), and minimum percentage (1.1\%) was in Madhurima. 
Prof. (Dr). Bandana Pandey et al.

Chart3. Type of Advertisements

\section{Bar Chart}

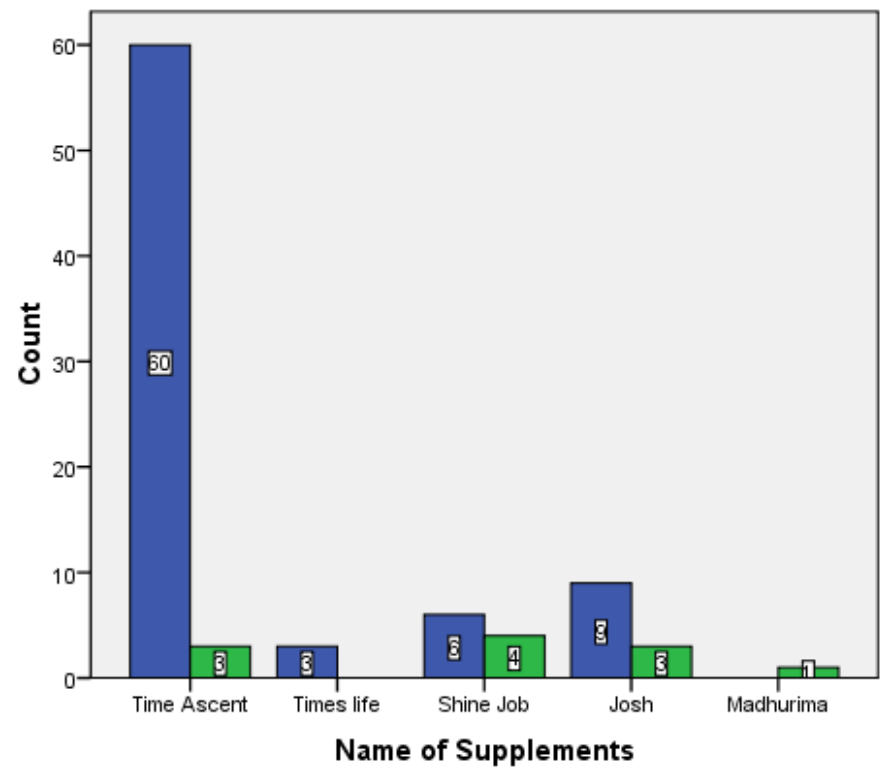

Type of Ads

口Display

Display Classified

Name of Supplements

Table6. Placement of Ads

\begin{tabular}{|c|c|c|c|c|c|c|}
\hline & \multicolumn{5}{|c|}{ Placement of Ads } & \multirow[t]{2}{*}{ Total } \\
\hline Supplements & Front page & Second page & Third page & Last page & Other page & \\
\hline \multirow[t]{2}{*}{ Time Ascent } & 2 & 4 & 11 & 12 & 34 & 63 \\
\hline & $28.6 \%$ & $28.6 \%$ & $64.7 \%$ & $75.0 \%$ & $97.1 \%$ & $70.8 \%$ \\
\hline \multirow[t]{2}{*}{ Times life } & 2 & 1 & 0 & 0 & 0 & 3 \\
\hline & $28.6 \%$ & $7.1 \%$ & $.0 \%$ & $.0 \%$ & $.0 \%$ & $3.4 \%$ \\
\hline \multirow[t]{2}{*}{ Shine Job } & 2 & 1 & 3 & 4 & 0 & 10 \\
\hline & $28.6 \%$ & $7.1 \%$ & $17.6 \%$ & $25.0 \%$ & $.0 \%$ & $11.2 \%$ \\
\hline \multirow[t]{2}{*}{ Josh } & 1 & 8 & 3 & 0 & 0 & 12 \\
\hline & $14.3 \%$ & $57.1 \%$ & $17.6 \%$ & $.0 \%$ & $.0 \%$ & $13.5 \%$ \\
\hline \multirow[t]{2}{*}{ Madhurima } & 0 & 0 & 0 & 0 & 1 & 1 \\
\hline & $.0 \%$ & $.0 \%$ & $.0 \%$ & $.0 \%$ & $2.9 \%$ & $1.1 \%$ \\
\hline \multirow[t]{2}{*}{ Total } & 7 & 14 & 17 & 16 & 35 & 89 \\
\hline & $100.0 \%$ & $100.0 \%$ & $100.0 \%$ & $100.0 \%$ & $100.0 \%$ & $100.0 \%$ \\
\hline
\end{tabular}

Chart4. Placement of Advertisements

\section{Bar Chart}

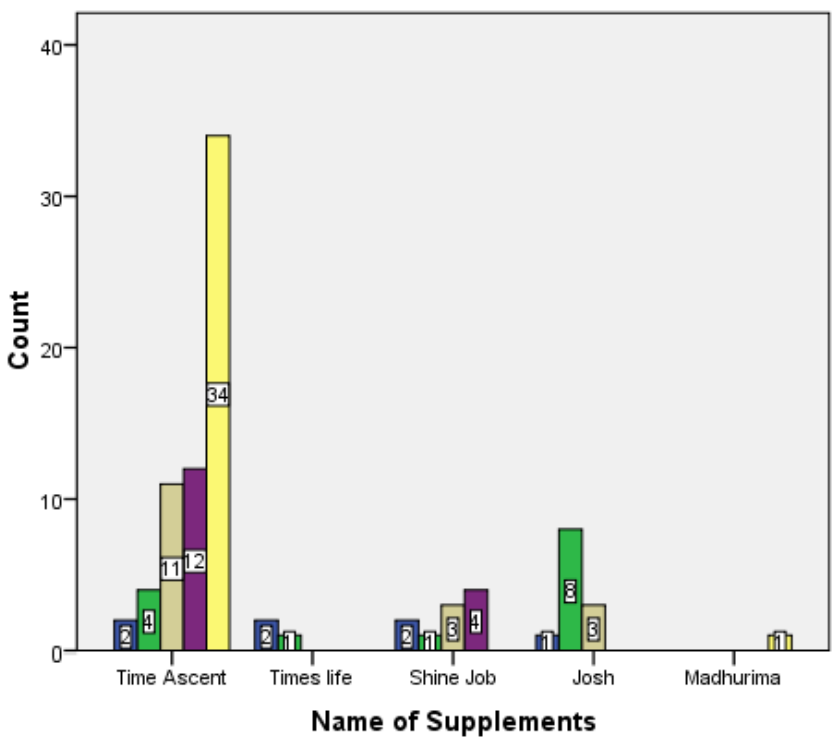


The placement of advertisement is very important owing to the difference in attention and significance of different pages by readers and also for the advertisers as different pages carry different positions where ad can be placed and those ads are charged according to the payment charts (Table-6, Chart-4). Ads placed on Front page, last page are more costly and so on. This table highlights that out of 89 ads maximum number 35 ads were published on other pages than first, second, third and last by Time Ascent $(97.1 \%)$ and (2.9\%) by Madhurima trailed by 17 ads which were published on third page, 16 on fourth page and 14 on second page. Minimum number of ads revealing women empowerment was published on front page i.e. 7. It can be seen that from $70.8 \%$ and $3.8 \%$ of ads published by Times Ascent and Times life, $28.6 \%$ of ads were published on front page by both of them and $28.6 \%$ and $7.1 \%$ on second page respectively. Shine job published its maximum ads strengthening women on last page $(25 \%)$ whereas Josh published them on second page nearly $(57.1 \%)$.

Table7. Position of Ads

\begin{tabular}{|l|l|l|l|l|l|l|}
\hline & \multicolumn{4}{|l}{ Position of Ads } & Total \\
\hline Supplements & Pointer Ad & Anchor Ad & Full page Ad & Half Page Ad & Other & \\
\hline \multirow{2}{*}{ Time Ascent } & 16 & 6 & 1 & 2 & 38 & 63 \\
\cline { 2 - 7 } & $59.3 \%$ & $100.0 \%$ & $50.0 \%$ & $25.0 \%$ & $82.6 \%$ & $70.8 \%$ \\
\hline \multirow{2}{*}{ Times life } & 0 & 0 & 0 & 2 & 1 & 3 \\
\cline { 2 - 7 } & $.0 \%$ & $.0 \%$ & $.0 \%$ & $25.0 \%$ & $2.2 \%$ & $3.4 \%$ \\
\hline \multirow{2}{*}{ Shine Job } & 3 & 0 & 1 & 3 & 3 & 10 \\
\cline { 2 - 7 } & $11.1 \%$ & $.0 \%$ & $50.0 \%$ & $37.5 \%$ & $6.5 \%$ & $11.2 \%$ \\
\hline \multirow{2}{*}{ Josh } & 8 & 0 & 0 & 1 & 3 & 12 \\
\cline { 2 - 7 } & $29.6 \%$ & $.0 \%$ & $.0 \%$ & $12.5 \%$ & $6.5 \%$ & $13.5 \%$ \\
\hline Madhurima & $0(.0 \%)$ & $0(.0 \%)$ & $0(.0 \%)$ & $0(.0 \%)$ & $1(2.2 \%)$ & $1(1.1 \%)$ \\
\hline Total & 27 & 6 & 2 & 8 & 46 & 89 \\
\cline { 2 - 6 } & $100.0 \%$ & $100.0 \%$ & $100.0 \%$ & $100.0 \%$ & $100.0 \%$ & $100.0 \%$ \\
\hline
\end{tabular}

Chart5. Position of Advertisements

\section{Bar Chart}
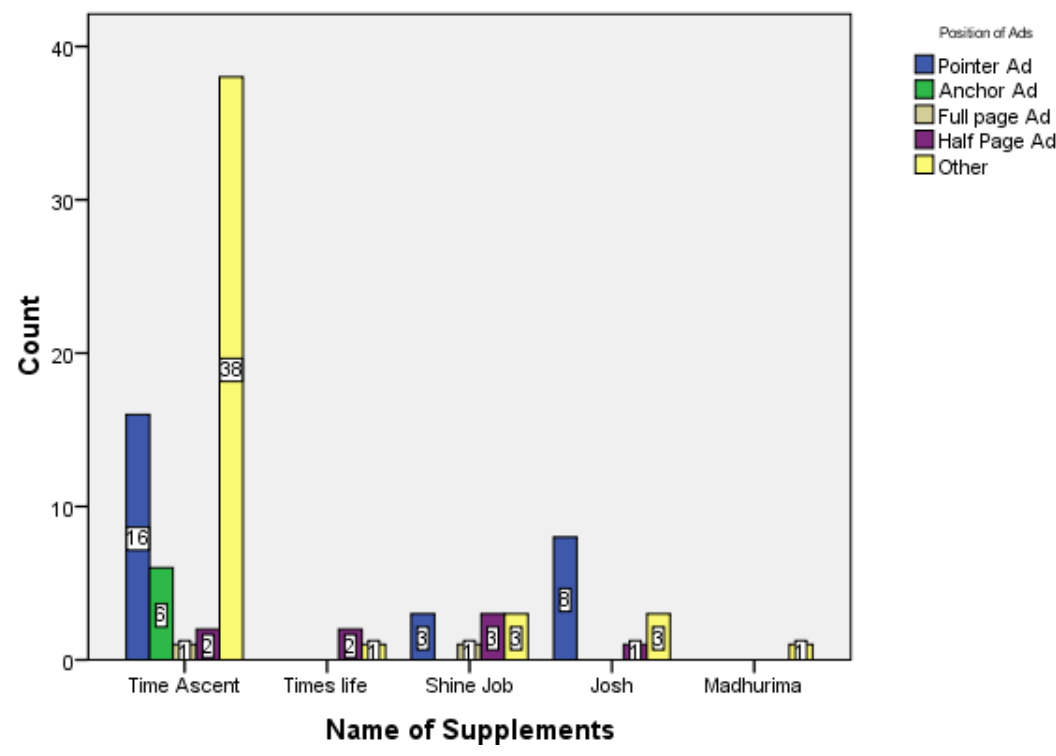

It is clear from Table-7, Chart-5 that only 2 ads portraying women empowerment were full page ad which were published by Time Ascent and Shine Job whereas 8 were half page ads out of which 3 were in Shine Job followed by Times Ascent \& Times life which published equal number of ads i.e. 2 and 1 half page ad was published by Josh. Out of 89 ads 27 were pointer ads. 59.3\% of them were published by Time Ascent and $29.6 \%$ pointer ad was published by Josh trailed by $11.1 \%$ by Shine Job. 6 out of total ads were Anchor ads published on the lower right side of the front page (Anchor ad) whereas maximum number that is 46 ads were placed on other positions of the newspaper like above the fold, below the fold, middle of the page etc. 
Prof. (Dr). Bandana Pandey et al.

Table8. Color of Ads

\begin{tabular}{|l|l|l|l|}
\hline Supplements & Frequency & Valid Percent & Cumulative Percent \\
\hline Coloured & 62 & 69.7 & 69.7 \\
\hline Black \& White & 27 & 30.3 & 100.0 \\
\hline Total & 89 & 100.0 & \\
\hline
\end{tabular}

Table9. Background Color of Ads

\begin{tabular}{|l|l|l|l|}
\hline Supplements & Frequency & Valid Percent & Cumulative Percent \\
\hline White & 43 & 48.3 & 48.3 \\
\hline Coloured & 37 & 41.6 & 89.9 \\
\hline Blurb & 9 & 10.1 & 100.0 \\
\hline Total & 89 & 100.0 & \\
\hline
\end{tabular}

Table- 8 and Table-9 show the Color and Background color carried by ads showing women empowerment. $69.7 \%$ of ads were colored and $30.3 \%$ were black and white. $48.3 \%$ of ads had white background, $41.6 \%$ had colored background and $10.1 \%$ was having blurb background i.e. colored visual on the black base.

Table10. Category of Ad

\begin{tabular}{|l|l|l|l|}
\hline \multirow{2}{*}{ Supplements } & \multicolumn{2}{|l|}{ Category of Ad } & \multirow{2}{*}{ Total } \\
\hline \multirow{3}{*}{ Time Ascent } & Commercial & Non - Commercial & \\
\hline \multirow{2}{*}{ Times life } & 61 & 2 & 63 \\
\cline { 2 - 4 } & $76.2 \%$ & $22.2 \%$ & $70.8 \%$ \\
\hline \multirow{2}{*}{ Shine Job } & 3 & 0 & 3 \\
\cline { 2 - 4 } & $3.8 \%$ & $.0 \%$ & $3.4 \%$ \\
\hline \multirow{2}{*}{ Josh } & 10 & 0 & 10 \\
\cline { 2 - 4 } & $12.5 \%$ & $.0 \%$ & $11.2 \%$ \\
\hline \multirow{2}{*}{ Madhurima } & 5 & 7 & 12 \\
\cline { 2 - 4 } & $6.2 \%$ & $77.8 \%$ & $13.5 \%$ \\
\hline Total & 1 & 0 & 1 \\
\cline { 2 - 4 } & $1.2 \%$ & $.0 \%$ & $1.1 \%$ \\
\cline { 2 - 4 } & 80 & 9 & $100 \%$ \\
\hline
\end{tabular}

Chart6. Category of Advertisements

\section{Bar Chart}

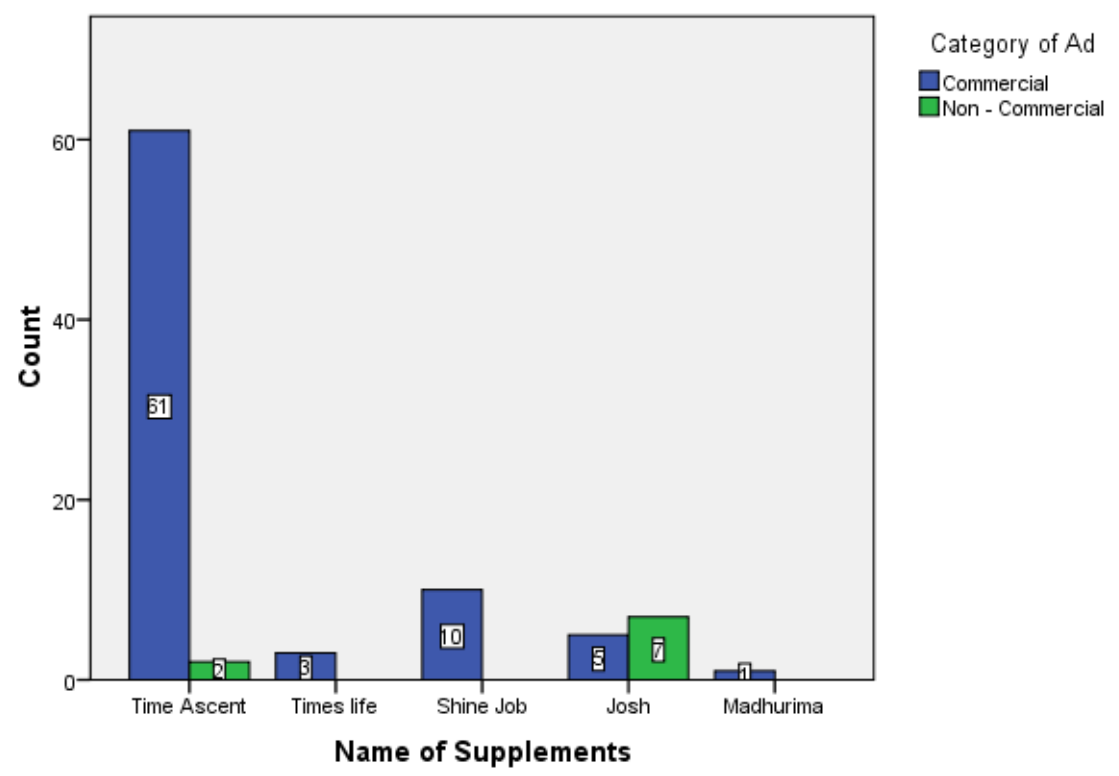

It is highlighted from Table-10, Chart-6, 80 ads of women were of commercial category and 9 ads were of Non-commercial category. Out of 80 ads $76.2 \%$ commercial ads were published by Time Ascent, $12.5 \%$ by Shine Job, $6.2 \%$ by Josh, $3.8 \%$ by Times Life and $1.2 \%$ by Madhurima. $77.8 \%$ ads of Non-commercial category were published by Josh and $22.2 \%$ by Time Ascent. 
Representation of Women through Print Advertisement: A Content Analysis of Advertisement of Newspaper Supplements

Table11. Product Category

\begin{tabular}{|c|c|c|c|c|c|c|}
\hline & \multicolumn{5}{|c|}{ Name of Supplements } & \multirow[t]{2}{*}{ Total } \\
\hline Supplements & Time Ascent & Times life & Shine Job & Josh & Madhurima & \\
\hline \multirow[t]{2}{*}{ Clothes } & 8 & 0 & 0 & 0 & 0 & 8 \\
\hline & $100.0 \%$ & $.0 \%$ & $.0 \%$ & $.0 \%$ & $.0 \%$ & $100.0 \%$ \\
\hline \multirow[t]{2}{*}{ Beverage } & 7 & 0 & 0 & 0 & 0 & 7 \\
\hline & $100.0 \%$ & $.0 \%$ & $.0 \%$ & $.0 \%$ & $.0 \%$ & $100.0 \%$ \\
\hline \multirow[t]{2}{*}{ Food } & 3 & 0 & 0 & 0 & 0 & 3 \\
\hline & $100.0 \%$ & $.0 \%$ & $.0 \%$ & $.0 \%$ & $.0 \%$ & $100.0 \%$ \\
\hline \multirow[t]{2}{*}{ Health } & 2 & 0 & 0 & 0 & 1 & 3 \\
\hline & $66.7 \%$ & $.0 \%$ & $.0 \%$ & $.0 \%$ & $33.3 \%$ & $100.0 \%$ \\
\hline \multirow[t]{2}{*}{ Education } & 8 & 0 & 2 & 2 & 0 & 12 \\
\hline & $66.7 \%$ & $.0 \%$ & $16.7 \%$ & $16.7 \%$ & $.0 \%$ & $100.0 \%$ \\
\hline \multirow[t]{2}{*}{ Technical } & 0 & 0 & 2 & 0 & 0 & 2 \\
\hline & $.0 \%$ & $.0 \%$ & $100.0 \%$ & $.0 \%$ & $.0 \%$ & $100.0 \%$ \\
\hline \multirow[t]{2}{*}{ Job } & 26 & 0 & 4 & 9 & 0 & 39 \\
\hline & $66.7 \%$ & $.0 \%$ & $10.3 \%$ & $23.1 \%$ & $.0 \%$ & $100.0 \%$ \\
\hline \multirow[t]{2}{*}{ Banking } & 4 & 2 & 2 & 0 & 0 & 8 \\
\hline & $50.0 \%$ & $25.0 \%$ & $25.0 \%$ & $.0 \%$ & $.0 \%$ & $100.0 \%$ \\
\hline \multirow[t]{2}{*}{ Award } & 2 & 0 & 0 & 0 & 0 & 2 \\
\hline & $100.0 \%$ & $.0 \%$ & $.0 \%$ & $.0 \%$ & $.0 \%$ & $100.0 \%$ \\
\hline \multirow[t]{2}{*}{ Other } & 3 & 1 & 0 & 1 & 0 & 5 \\
\hline & $60.0 \%$ & $20.0 \%$ & $.0 \%$ & $20.0 \%$ & $.0 \%$ & $100.0 \%$ \\
\hline \multirow[t]{2}{*}{ Total } & 63 & 3 & 10 & 12 & 1 & 89 \\
\hline & $70.8 \%$ & $3.4 \%$ & $11.2 \%$ & $13.5 \%$ & $1.1 \%$ & $100.0 \%$ \\
\hline
\end{tabular}

Chart7. Product Category

\section{Bar Chart}
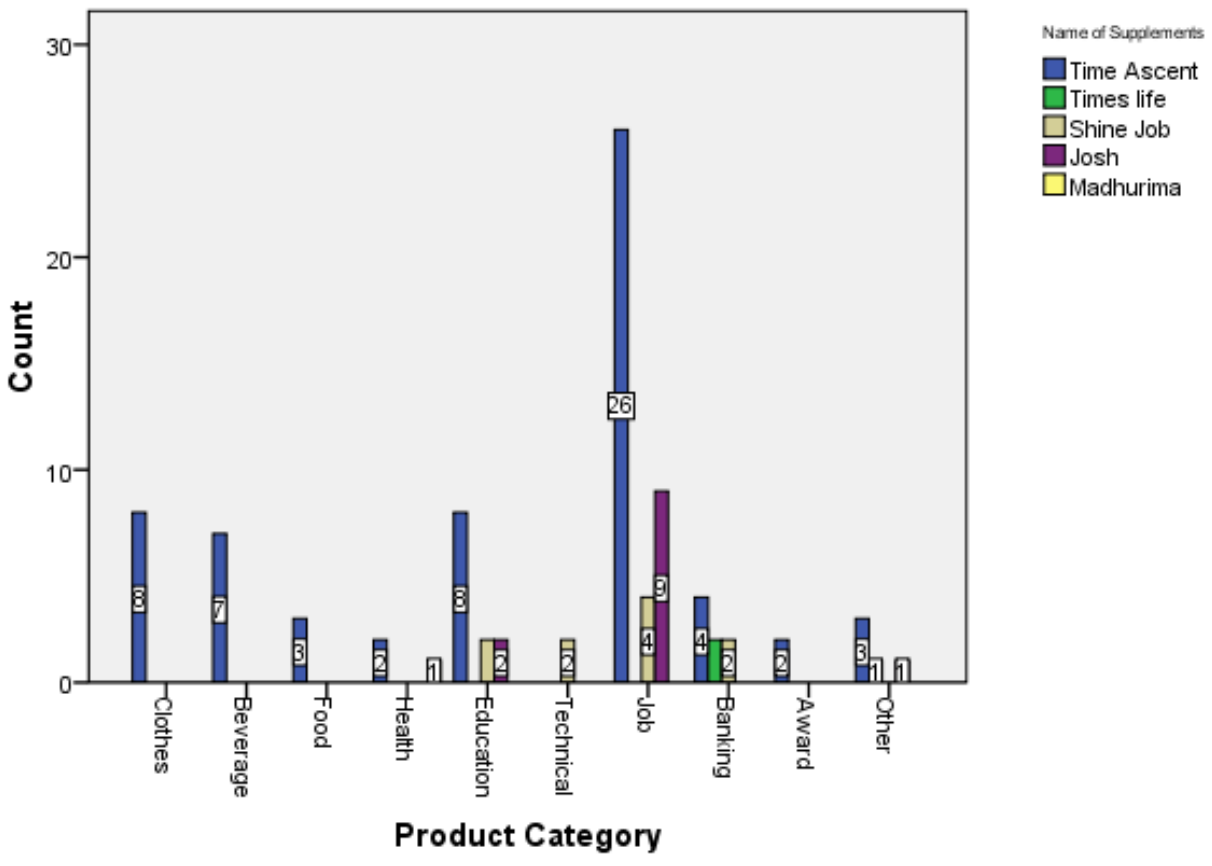

Table-11, Chart-7 given below depicts that maximum ads portraying women empowerment i.e. $66.7 \%$ ads were published by Time Ascent, $23.1 \%$ published by Josh and $10.3 \%$ by Shine job were related to Job. Out of 89 ads 8 ads were of clothes, 7 were of beverage category, 3 were of food and 2 were of award solely published by Time Ascent. Out of 12 ads related to education, $66.7 \%$ were published in Time Ascent and $16.7 \%$ by Josh and Shine job each. There were only 2 technical ads showing empowered women and they were in Shine Job. Ads related to banking were 8 in number, $50 \%$ of which was published by Time Ascent and equal percent (25\%) was published by Times Life and Shine Job both. 5 ads were related to other product category and 3 out of 89 were of heath related. 
Prof. (Dr). Bandana Pandey et al.

Table12. Types of Appeals

\begin{tabular}{|c|c|c|c|c|}
\hline & \multicolumn{3}{|l|}{ Appeals } & \multirow[t]{2}{*}{ Total } \\
\hline Supplements & Rational & Emotional & Rational+ Emotional & \\
\hline \multirow{2}{*}{ Time Ascent } & 49 & 13 & 1 & 63 \\
\hline & $77.8 \%$ & $54.2 \%$ & $50.0 \%$ & $70.8 \%$ \\
\hline \multirow[t]{2}{*}{ Times life } & 0 & 2 & 1 & 3 \\
\hline & $.0 \%$ & $8.3 \%$ & $50.0 \%$ & $3.4 \%$ \\
\hline \multirow[t]{2}{*}{ Shine Job } & 3 & 7 & 0 & 10 \\
\hline & $4.8 \%$ & $29.2 \%$ & $.0 \%$ & $11.2 \%$ \\
\hline \multirow[t]{2}{*}{ Josh } & 10 & 2 & 0 & 12 \\
\hline & $15.9 \%$ & $8.3 \%$ & $.0 \%$ & $13.5 \%$ \\
\hline \multirow[t]{2}{*}{ Madhurima } & 1 & 0 & 0 & 1 \\
\hline & $1.6 \%$ & $.0 \%$ & $.0 \%$ & $1.1 \%$ \\
\hline \multirow[t]{2}{*}{ Total } & 63 & 24 & 2 & 89 \\
\hline & $100.0 \%$ & $100.0 \%$ & $100.0 \%$ & $100.0 \%$ \\
\hline
\end{tabular}

Chart8. Appeals used in Advertisements

\section{Bar Chart}

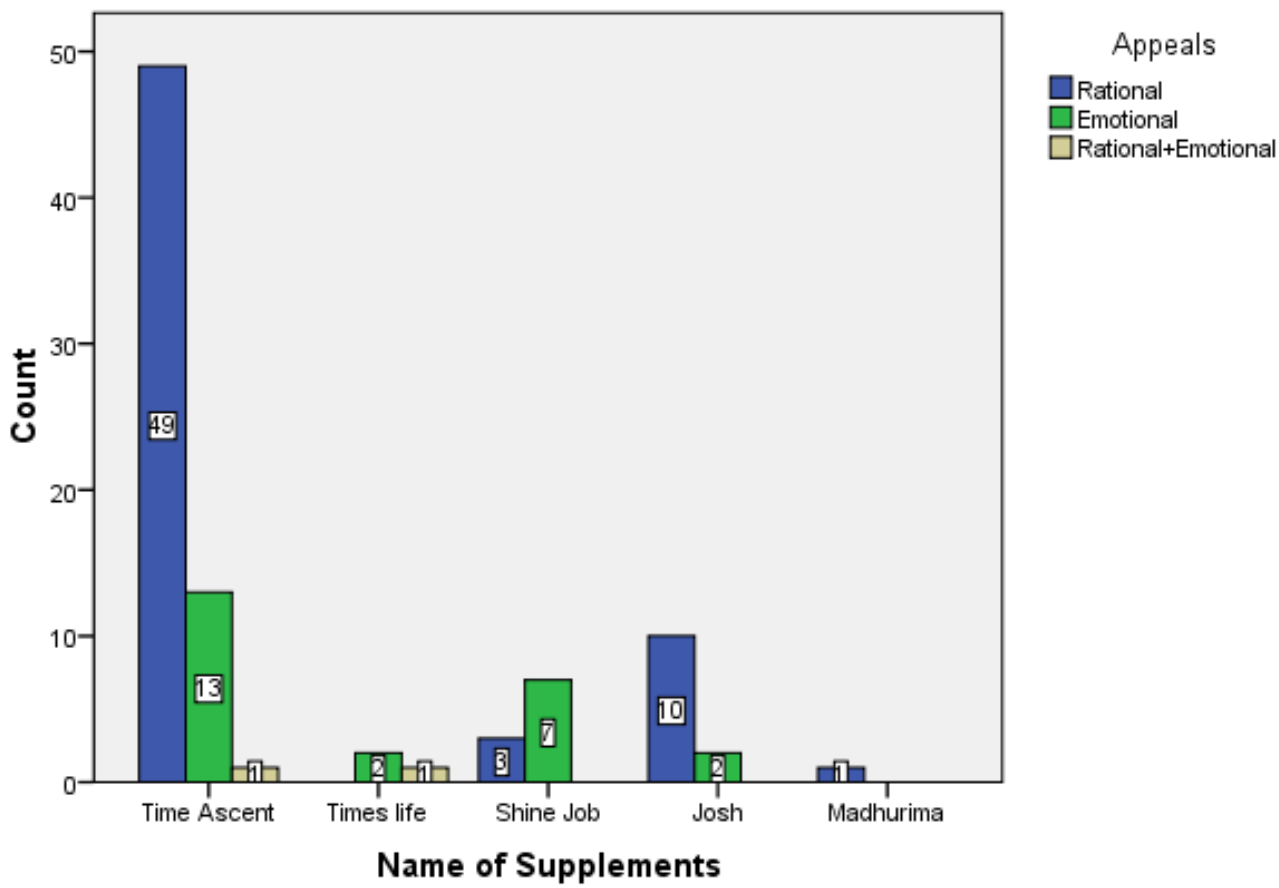

Table-12 and Chart-8 indicates that advertisements portraying women empowerment had 3 appeals in them. They were Rational, Emotional and Rational-Emotional together. From all the ads 24 ads were revealing women with emotional appeal and 63 were of rational appeal. 54.2\% ads showing emotional appeal and $77.8 \%$ ads related to rational appeal were published by Time Ascent alone and 15.9\% related to rational appeal by Josh and least percentage was published by Shine Job and Madhurima i.e. $4.8 \%$ and $1.6 \%$ respectively. There were only 2 ads in all the supplements which showed Rational Emotional appeal together as one of them was of Liberty Footwear which compelled the target audience to buy the product as carrying that product she can look beautiful with confidence and comfort. And the other was of Job related to Airways (cabin crew) joining which gives lot of money, joy, satisfaction and would make every dream come true of the employee eligible for the job.

Table13. Elements of Advertisements

\begin{tabular}{|l|l|l|l|l|l|}
\hline Ad Elements & Headline & Sub- Headline & Body Copy & Visual & Logo \\
\hline Yes & $85(95.5 \%)$ & $85(95.5 \%)$ & $86(96.6 \%)$ & $89(100 \%)$ & $84(94.6 \%)$ \\
\hline No & $4(4.5 \%)$ & $4(4.5 \%)$ & $3(3.4 \%)$ & - & $5(5.6 \%)$ \\
\hline Total & $89(100 \%)$ & $89(100 \%)$ & $89(100 \%)$ & $89(100 \%)$ & $89(100 \%)$ \\
\hline
\end{tabular}

Table-13 depicts Ad elements shown in 89 advertisements portraying women empowerment. 85 (95.5\%) of them were having Headline and Sub- Headline both. 89 (100\%) ads contained visuals. 
Representation of Women through Print Advertisement: A Content Analysis of Advertisement of Newspaper Supplements

94.6\% ads had logos whereas 5.6\% of them did not have logos. 96.6\% of ads contained Body Copy which was missing in $3.4 \%$ of ads.

Table14. Appearance of Ad

\begin{tabular}{|c|c|c|c|c|c|}
\hline & \multicolumn{4}{|c|}{ Appearance of Ad } & \multirow[t]{2}{*}{ Total } \\
\hline Supplements & Female & Male + female & Female + children & Female+ male +children & \\
\hline \multirow{2}{*}{ Time Ascent } & 45 & 18 & 0 & 0 & 63 \\
\hline & $73.8 \%$ & $78.3 \%$ & $.0 \%$ & $.0 \%$ & $70.8 \%$ \\
\hline \multirow[t]{2}{*}{ Times life } & 2 & 0 & 0 & 1 & 3 \\
\hline & $3.3 \%$ & $.0 \%$ & $.0 \%$ & $100.0 \%$ & $3.4 \%$ \\
\hline \multirow{2}{*}{ Shine Job } & 9 & 1 & 0 & 0 & 10 \\
\hline & $14.8 \%$ & $4.3 \%$ & $.0 \%$ & $.0 \%$ & $11.2 \%$ \\
\hline \multirow[t]{2}{*}{ Josh } & 5 & 3 & 4 & 0 & 12 \\
\hline & $8.2 \%$ & $13.0 \%$ & $100.0 \%$ & $.0 \%$ & $13.5 \%$ \\
\hline \multirow[t]{2}{*}{ Madhurima } & 0 & 1 & 0 & 0 & 1 \\
\hline & $.0 \%$ & $4.3 \%$ & $.0 \%$ & $.0 \%$ & $1.1 \%$ \\
\hline \multirow[t]{2}{*}{ Total } & 61 & 23 & 4 & 1 & 89 \\
\hline & $100.0 \%$ & $100.0 \%$ & $100.0 \%$ & $100.0 \%$ & $100.0 \%$ \\
\hline
\end{tabular}

Chart9. Appearance of Advertisement

\section{Bar Chart}

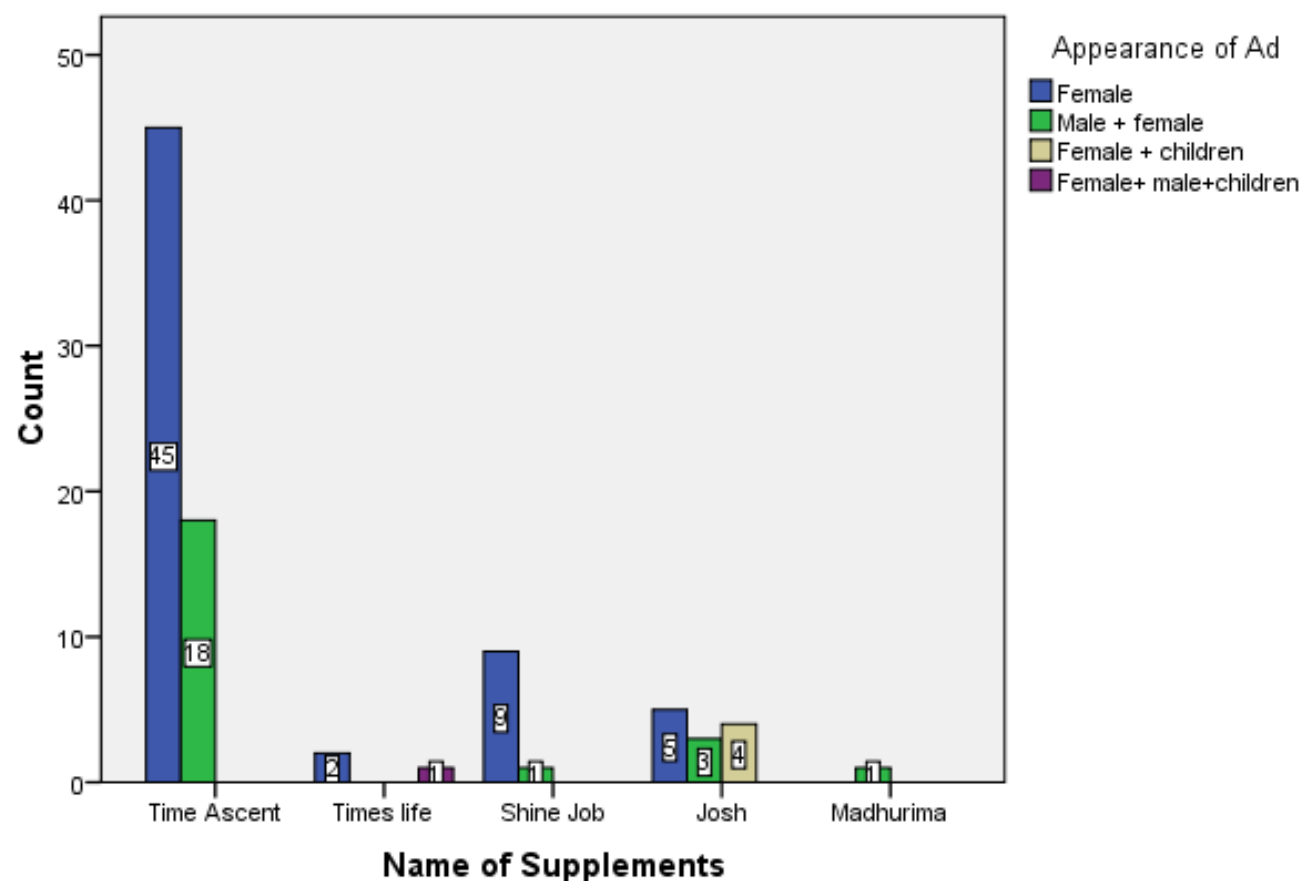

Table-14, Chart-9 describes that 61 ads had females in them in which maximum i.e. $73.8 \%$ ads were published by Time Ascent whereas 23 advertisements had visuals of male and female both in which maximum $78.3 \%$ was published by Time Ascent and minimum (4.3\%) was published by Shine Job. 4 ads had female and children both and was published in Josh and only 1 ad of Liberty footwear was having visual of male, female and children and was found in Times Life. It was the single ad in which male, female and child appeared.

Table15. Classification of Ad

\begin{tabular}{|l|l|l|l|l|l|}
\hline & \multicolumn{3}{|l|}{ Classification of Ad } & \multirow{2}{*}{ Total } \\
\hline Supplements & Model & Actor/Actress & Ordinary & Celebrity & \\
\hline \multirow{2}{*}{ Time Ascent } & 22 & 3 & 37 & 1 & 63 \\
\cline { 2 - 5 } & $68.8 \%$ & $75.0 \%$ & $75.5 \%$ & $25.0 \%$ & $70.8 \%$ \\
\hline \multirow{2}{*}{ Times life } & 0 & 0 & 0 & 3 & 3 \\
\cline { 2 - 5 } & $.0 \%$ & $.0 \%$ & $.0 \%$ & $75.0 \%$ & $3.4 \%$ \\
\hline
\end{tabular}


Prof. (Dr). Bandana Pandey et al.

\begin{tabular}{|l|l|l|l|l|l|}
\hline \hline \multirow{2}{*}{ Shine Job } & 10 & 0 & 0 & 0 & 10 \\
\cline { 2 - 6 } & $31.2 \%$ & $.0 \%$ & $.0 \%$ & $.0 \%$ & $11.2 \%$ \\
\hline \multirow{3}{*}{ Josh } & 0 & 0 & 12 & 0 & 12 \\
\cline { 2 - 6 } & $.0 \%$ & $.0 \%$ & $24.5 \%$ & $.0 \%$ & $13.5 \%$ \\
\hline \multirow{2}{*}{ Madhurima } & 0 & 1 & 0 & 0 & 1 \\
\cline { 2 - 6 } & $.0 \%$ & $25.0 \%$ & $.0 \%$ & $.0 \%$ & $1.1 \%$ \\
\hline \multirow{2}{*}{ Total } & 32 & 4 & 49 & 4 & 89 \\
\cline { 2 - 6 } & $100.0 \%$ & $100.0 \%$ & $100.0 \%$ & $100.0 \%$ & $100.0 \%$ \\
\hline
\end{tabular}

Chart10. Classification of Advertisements

\section{Bar Chart}
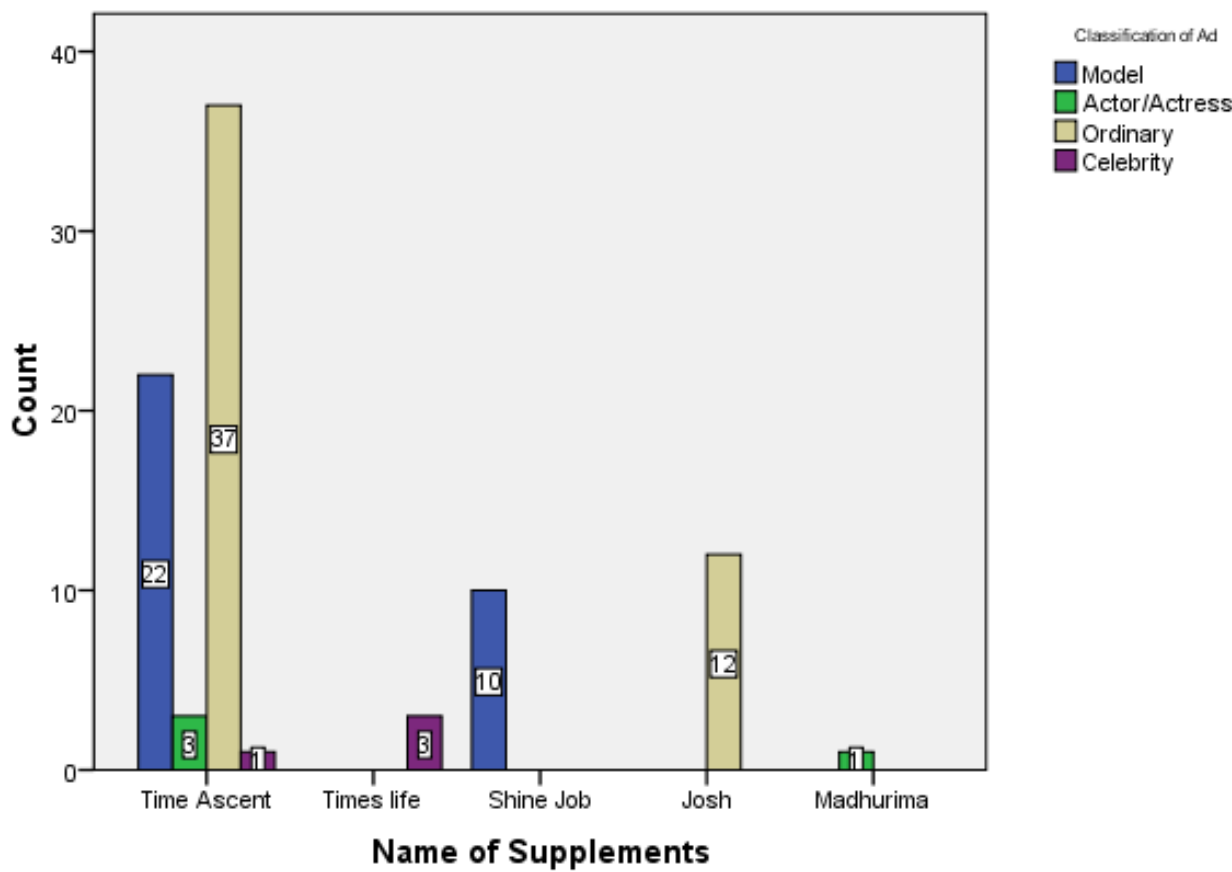

Table-15 \& Chart-10 depicts the classification of advertisements on the basis of characters (Models, Celebrities, Actress, Ordinary women) which decides the popularity and cost of the ad. It shows that of all the ads showing women empowerment 32 ads had Models in them from which $68.8 \%$ ads were published by Time Ascent and $31.2 \%$ by Shine Job. Maximum Ads (37) had ordinary females in them out of which $75.5 \%$ were published in Time Ascent and $24.5 \%$ ads by Josh. Very less percentage was given to the ads having Actress and celebrities in them i.e. only 4 in number. It clearly shows that the target audience of these ads is ordinary and simple household women who believe in simplicity.

Table16. Language of Ad

\begin{tabular}{|l|l|l|l|}
\hline Supplements & Frequency & Valid Percent & Cumulative Percent \\
\hline English & 86 & 96.6 & 96.6 \\
\hline Bilingual & 2 & 2.2 & 98.9 \\
\hline Hindi & 1 & 1.1 & 100.0 \\
\hline Total & 89 & 100.0 & \\
\hline
\end{tabular}

Table-16 describes that $96.6 \%$ of Ads had English Language, $1.1 \%$ ads were in Hindi and $2.2 \%$ ads were bilingual in nature. It was interesting to note that all Hindi supplements had ads in English except 1 in Josh which was bilingual and the most important thing was that all the ads had picture and portrait of women in them and no animated ad of women was found in the supplements.

Table17. Background Location of Ads

\begin{tabular}{|l|l|l|l|l|l|l|}
\hline $\begin{array}{l}\text { Background } \\
\text { locations }\end{array}$ & \multicolumn{4}{|l|}{ Name of Supplements } & \multirow{2}{*}{ Total } \\
\hline & Time Ascent & Times life & Shine Job & Josh & Madhurima & \\
\hline \multirow{2}{*}{ Garden } & 0 & 0 & 0 & 1 & 0 & 1 \\
\cline { 2 - 7 } & $.0 \%$ & $.0 \%$ & $.0 \%$ & $100.0 \%$ & $.0 \%$ & $100.0 \%$ \\
\hline Home & 0 & 2 & 0 & 0 & 0 & 2 \\
\hline
\end{tabular}


Representation of Women through Print Advertisement: A Content Analysis of Advertisement of Newspaper Supplements

\begin{tabular}{|l|l|l|l|l|l|l|}
\hline \hline & $.0 \%$ & $100.0 \%$ & $.0 \%$ & $.0 \%$ & $.0 \%$ & $100.0 \%$ \\
\hline \multirow{3}{*}{ Office } & 16 & 0 & 0 & 6 & 1 & 23 \\
\cline { 2 - 7 } & $69.6 \%$ & $.0 \%$ & $.0 \%$ & $26.1 \%$ & $4.3 \%$ & $100.0 \%$ \\
\hline \multirow{3}{*}{ Building } & 1 & 0 & 0 & 3 & 0 & 4 \\
& $25.0 \%$ & $.0 \%$ & $.0 \%$ & $75.0 \%$ & $.0 \%$ & $100.0 \%$ \\
\hline \multirow{3}{*}{ Kitchen } & 1 & 0 & 0 & 0 & 0 & 1 \\
\cline { 2 - 7 } & $100.0 \%$ & $.0 \%$ & $.0 \%$ & $.0 \%$ & $.0 \%$ & $100.0 \%$ \\
\hline \multirow{3}{*}{ Classroom } & 7 & 0 & 0 & 1 & 0 & 8 \\
\cline { 2 - 7 } & $87.5 \%$ & $.0 \%$ & $.0 \%$ & $12.5 \%$ & $.0 \%$ & $100.0 \%$ \\
\hline \multirow{3}{*}{ Parlour } & 4 & 0 & 0 & 0 & 0 & 4 \\
\hline \multirow{3}{*}{ Other } & $100.0 \%$ & $.0 \%$ & $.0 \%$ & $.0 \%$ & $.0 \%$ & $100.0 \%$ \\
\cline { 2 - 7 } & 20 & 0 & 0 & 1 & 0 & 21 \\
\hline \multirow{2}{*}{ None } & $95.2 \%$ & $.0 \%$ & $.0 \%$ & $4.8 \%$ & $.0 \%$ & $100.0 \%$ \\
\cline { 2 - 7 } & 14 & 1 & 10 & 0 & 0 & 25 \\
\hline \multirow{2}{*}{ Total } & $56.0 \%$ & $4.0 \%$ & $40.0 \%$ & $.0 \%$ & $.0 \%$ & $100.0 \%$ \\
\cline { 2 - 7 } & 63 & 3 & 10 & 12 & 1 & 89 \\
\cline { 2 - 7 } & $70.8 \%$ & $3.4 \%$ & $11.2 \%$ & $13.5 \%$ & $1.1 \%$ & $100.0 \%$ \\
\hline
\end{tabular}

Chart11. Background Locations of the Advertisements

\section{Bar Chart}

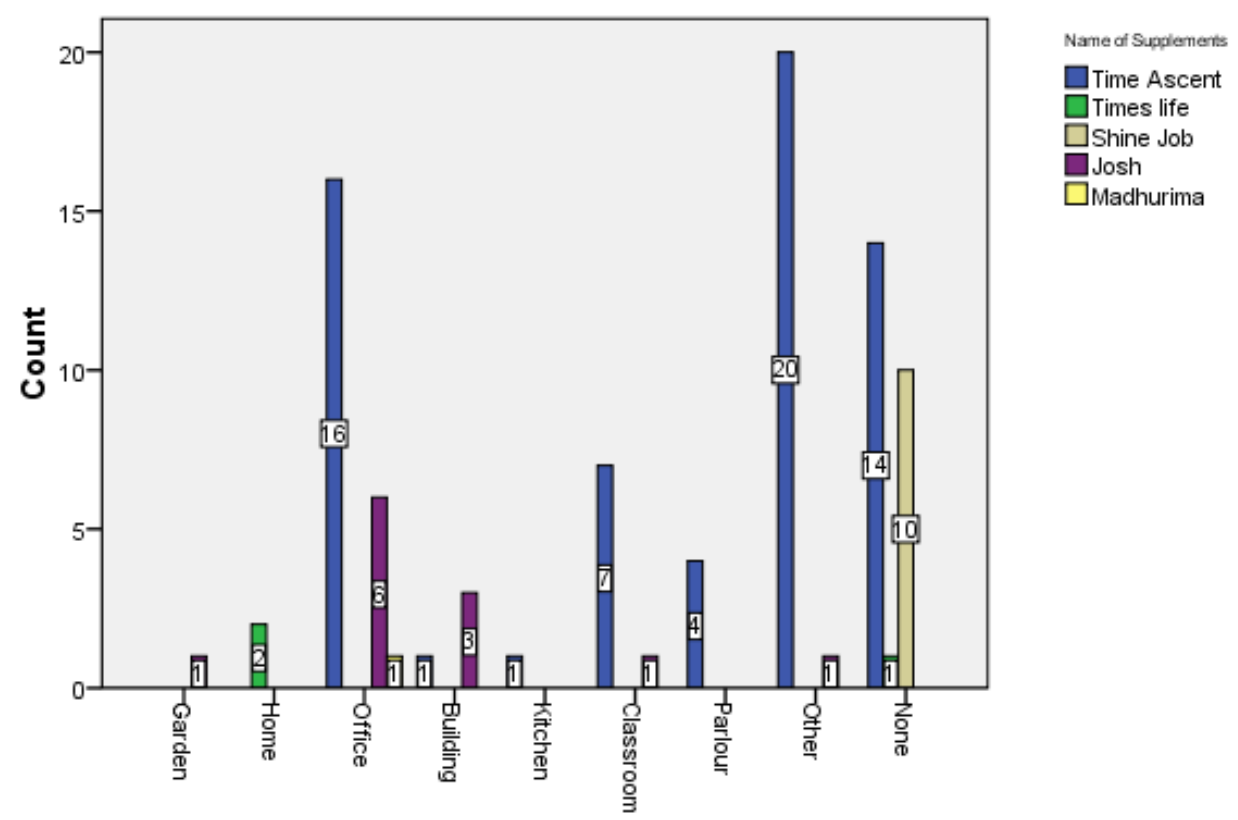

Background location of Ads

Table-17, Chart-11 shows the background location in the ads through which empowered women is shown. Maximum number of ads (25) had nothing and 23 of them had office located in the background followed by 2 ads which had home, 4 of them had building and parlor each at their back, 8 ads had classroom shown in them and 1 were having kitchen and garden each and 21 of them had other things in their background. $69.6 \%$ ads having office were published by Time Ascent and $26.1 \%$ by Josh.

Table18. Theme of Ads

\begin{tabular}{|c|c|c|c|c|c|c|}
\hline & \multicolumn{5}{|c|}{ Theme of Ads } & \multirow[t]{2}{*}{ Total } \\
\hline Supplements & Spritiual & Social & Educational & Professional & Other & \\
\hline \multirow[t]{2}{*}{ Time Ascent } & 3 & 7 & 13 & 35 & 5 & 63 \\
\hline & $100.0 \%$ & $30.4 \%$ & $65.0 \%$ & $94.6 \%$ & $83.3 \%$ & $70.8 \%$ \\
\hline \multirow[t]{2}{*}{ Times life } & 0 & 3 & 0 & 0 & 0 & 3 \\
\hline & $.0 \%$ & $13.0 \%$ & $.0 \%$ & $.0 \%$ & $.0 \%$ & $3.4 \%$ \\
\hline \multirow[t]{2}{*}{ Shine Job } & 0 & 0 & 7 & 2 & 1 & 10 \\
\hline & $.0 \%$ & $.0 \%$ & $35.0 \%$ & $5.4 \%$ & $16.7 \%$ & $11.2 \%$ \\
\hline
\end{tabular}


Prof. (Dr). Bandana Pandey et al.

\begin{tabular}{|l|l|l|l|l|l|l|}
\hline \hline \multirow{2}{*}{ Josh } & 0 & 12 & 0 & 0 & 0 & 12 \\
\cline { 2 - 7 } & $.0 \%$ & $52.2 \%$ & $.0 \%$ & $.0 \%$ & $.0 \%$ & $13.5 \%$ \\
\hline \multirow{3}{*}{ Madhurima } & 0 & 1 & 0 & 0 & 0 & 1 \\
\cline { 2 - 7 } & $.0 \%$ & $4.3 \%$ & $.0 \%$ & $.0 \%$ & $.0 \%$ & $1.1 \%$ \\
\hline \multirow{2}{*}{ Total } & 3 & 23 & 20 & 37 & 6 & 89 \\
\cline { 2 - 7 } & $100.0 \%$ & $100.0 \%$ & $100.0 \%$ & $100.0 \%$ & $100.0 \%$ & $100.0 \%$ \\
\hline
\end{tabular}

Chart12. Theme of Advertisements

\section{Bar Chart}

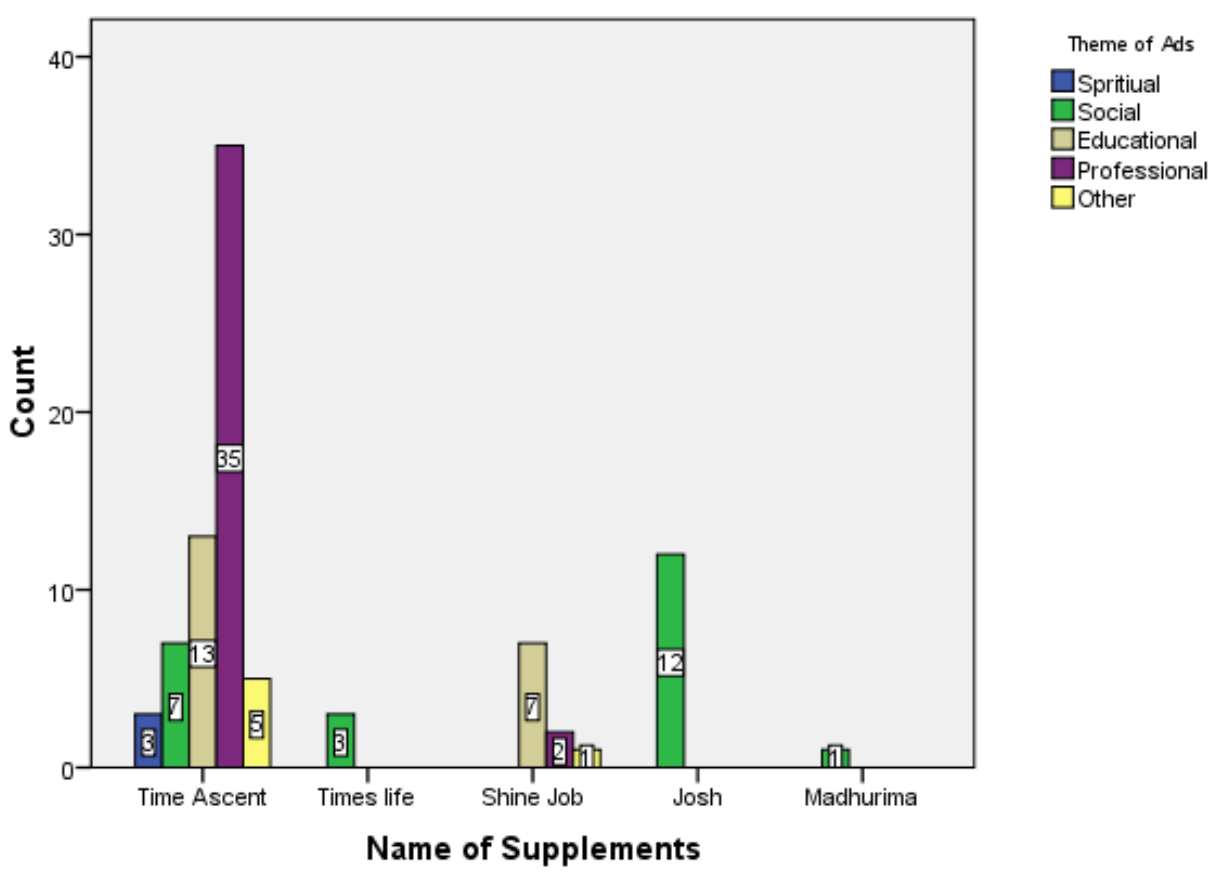

Table-18 \& Chart-12 describes the theme of advertisements through which empowerment of women is shown. It is interesting to note that maximum ads (37) were professional ads out of which $94.6 \%$ was published by Time Ascent and $5.4 \%$ by Shine Job. $65 \%$ of educational ads were published in Time Ascent and 35\% was published by Shine Job. 52.2\% of social ads were published in Josh, $30.4 \%$ by Time Ascent, $13 \%$ of them were in Times Life and $4.3 \%$ were in Madhurima. There were only 3 spiritual ads and all were present in Time Ascent whereas 6 were related to other themes like might and strength etc. This shows that in this era when women and men are treated equally, women are given opportunity to work so that they can consider themselves equal to men.

\section{Findings and Conclusions}

1. It was found that in 188 supplements of four Indian dailies of 6 months; total 6817 advertisements were published in which only 89 advertisements $(1.3 \%)$ portraying women empowerment was found.

2. It was seen that Supplements of TOI (Times life, Time Ascent) published maximum (70.79\%) ads portraying women empowerment trailed by Josh (13.48\%) (Supplement of Dainik Jagran) followed by Shine Job $(11.24 \%)$ and the least ads portraying women empowerment were published by Madhurima (1.12\%) (Supplement of Dainik Bhaskar).

3. Eight supplements under study didn't publish any advertisement portraying women empowerment.

4. There is a direct relationship between the space provided to total content and total ads by the supplements of each newspaper and the advertisements through which empowerment of women is shown.

5. TOI (Time Ascent and Times Life) gave content, ads as well as the ads portraying empowerment, the maximum space that is $515630 \mathrm{sq} . \mathrm{cm}, 317255.75 \mathrm{sq} . \mathrm{cm}$, and 19635 sq. cm. respectively followed by HT (Shine Job) \& Dainik Jagran (Josh). The least space was given by Dainik 
Bhaskar (Madhurima) 16854 sq. $\mathrm{cm}$. and 400 sq. $\mathrm{cm}$. to total ads and to ads representing empowered women. It is clear from the figures that Hindi dailies had very less advertisements showing women empowerment so it is suggested that they should focus more on these types of advertisements so that women can see themselves with respect and dignity.

6. It was seen that $87.6 \%$ ads were display ads and $12.4 \%$ were display classified ads from which maximum display ads were published by Time Ascent (67.4\%) followed by Josh, Shine Job and Times Life $(10.1 \%),(6.7 \%)$ and $(3.4 \%)$ respectively. This shows that viewers are attracted by colors and visuals.

7. Only $12.4 \%$ ads were display classified ads in which least percentage $1.1 \%$ was published in Madhurima.

8. It was found that minimum number of ads revealing women empowerment was published on front page i.e. 7 and maximum number 35 ads were published on other pages other than first, second, third and last by Time Ascent (97.1\%) and (2.9\%) by Madhurima trailed by 17 ads which were published on third page, 16 on fourth page and 14 on second page. It is suggested that maximum ads should be placed on pages where OTS (opportunity to see) is more like front or last page.

9. It was clear that out of 89 ads 27 were pointer ads. 59.3\% of them were published by Time Ascent and $29.6 \%$ pointer ads were published by Josh trailed by $11.1 \%$ by Shine Job. 6 out of total ads were Anchor ads published on the lower right side of the front page.

10. Maximum number that is 46 ads were placed on other random positions of the supplement like above the fold, below the fold, middle of the page etc. The advertisers should place their advertisements at such positions where it can grab the attention of the viewers and the target audience.

11. $69.7 \%$ of ads were colored and $30.3 \%$ were black and white and as far as the background color is concerned, $48.3 \%$ of ads had white background, $41.6 \%$ had colored background and $10.1 \%$ was having blurb background i.e. colored visual on the black base.

12. It is a very significant finding that approximately $90 \%$ ads $(89.88 \%)$ portraying women empowerment were of commercial category and maximum of which $76.2 \%$ was published by Time Ascent, $12.5 \%$ by Shine Job, $6.2 \%$ by Josh, $3.8 \%$ by Times Life and $1.2 \%$ by Madhurima. It shows that woman is widely used to advertise commercial product than non-commercial one.

13. $77.8 \%$ ads of Non-commercial category ( $10.11 \%$ of total ads) were published by Josh and $22.2 \%$ by Time Ascent.

14. $66.7 \%$ ads were published by Time Ascent, $23.1 \%$ published by Josh and $10.3 \%$ by Shine job were related to Job (total 39 out of 89 ads) which is noticeable as jobs for women are advertised more than any other product category.

15. There were only 2 technical ads showing empowered women and they were in Shine Job. It is suggested that advertisers should place more ads which are technical in nature so as to create awareness for technology among women.

16. 2 ads from 89 ads in all the supplements which showed Rational - Emotional appeal together were noticed during the research as they touched the emotions of the target audience and compelled them to think about the product or job seriously.

17. It was found that 61 ads had only females, $73.8 \%$ of which were published by Time Ascent whereas 23 of them had visuals of male and female both from which maximum $78.3 \%$ was published by Time Ascent and minimum (4.3\%) was published by Shine Job. 4 ads had female and children both and was published in Josh.

18. Only 1 ad of Liberty footwear was having visual of male, female and children and was found in Times Life.

19. It was seen that maximum ads (37) had ordinary females in them out of which $75.5 \%$ were published in Time Ascent and $24.5 \%$ ads by Josh. It clearly shows that the target audience of these ads is ordinary and simple household women who believe in simplicity. 
20. Very less percentage was given to the ads having Actress and celebrities in them i.e. only 4 in number.

21. $96.6 \%$ of Ads had English Language, $1.1 \%$ ads were in Hindi and 2.2\% ads were bilingual in nature. It is interesting to note that advertisements' portraying women empowerment in Hindi supplement (Josh and Madhurima) was published in English only and 1 ad was bilingual in nature in Josh. No ad in Hindi was published in Hindi dialies' supplements.

22. Maximum number of ads (25) had nothing and 23 of them had office located in the background followed by 2 ads which had home, 4 of them had building and parlor each at their back, 8 ads had classroom shown in them and 1 were having kitchen and garden each and 21 of them had other things in their background. This indicates that today working women who can take their own decisions are shown more in ads which prove to be a milestone in changing her image in the society.

23. It was a significant finding that maximum ads (37) were professional ads out of which $94.6 \%$ was published by Time Ascent and $5.4 \%$ by Shine Job. $65 \%$ of educational ads were published in Time Ascent and 35\% was published by Shine Job. This shows that in this era when women and men are treated equally, women are given opportunity to work so that they can consider themselves equal to men.

\section{Conclusions}

The study concluded that in 188 supplements of four Indian dailies of 6 months out of 6817 ads published in supplements only 89 advertisements i.e. very less percentage of ads (1.3\%) portraying women empowerment was found. It can be inferred that minimum number of ads showing women empowerment was published on front page i.e. 7 and maximum number 35 ads were published on other pages other than first, second, third and last by Time Ascent (97.1\%) and (2.9\%) by Madhurima trailed by 17 ads which were published on third page and was found that premium pages didn't turn up with sufficient ads through which empowerment of women is seen which is really surprising. It was also seen that supplements of TOI (Times life, Time Ascent) published maximum (70.79\%) ads portraying women empowerment trailed by Josh (13.48\%) (Supplement of Dainik Jagran) followed by Shine Job (11.24\%) and the least ads portraying women empowerment were published by Madhurima (1.12\%) (Supplement of Dainik Bhaskar). Hindi dailies had published least percentage of these ads and hence all the hypotheses coined by the researcher were disapproved. The extent of ads related to women was less and to that of ads showing strength of women was nearly negligible thus providing least exposure to females despite of the fact that they are no less than males in today's world.

\section{REFERENCES}

HajiMohammadi, A. (2011). Critical analysis of women's representation in TV advertisements from a cultural studies perspective. International Journal of Women's Research, 1, 107-122.

Holtzhausen, T. (2010). Content Analysis Of Roles Portrayed By Women In Advertisements In Selected South African Media (Doctoral dissertation, University of Pretoria). Retrieved from http://repository.up.ac.za/bitstream/handle/2263/25084/Complete.pdf?sequence=10

Holtzhausen, T., Jordaan, Y., \& North, E. J. (2011). The portrayal of women in South African television commercials. Southern African Business Review, 15(3), 167-83. Retrieved from http://www.ajol.info/index.php/sabr/article/viewFile/76410/66868

Jacob, A. (2013). The Concept and Profile of Women's Empowerment in India. Retrieved from http://shodhganga.inflibnet.ac.in/bitstream/10603/8562/9/09_chapter\%204.pdf

Manuh, T. (2006, July 4). Conceptualizing Women's Empowerment. Retrieved from http://s3-euwest-1.amazonaws.com/pathwaysofempowerment-org-staging/ downloads/ conceptualising women_s_empowerment_in_west_africa_original3ebd1a01b314fed46479997fa77befbb.pdf

Nachmias, D. \& Nachmias, C. (1976). Content analysis. In Research methods in the social sciences (pp 132-139), UK: Edward Arnold

Paterson, R. (2004). Women's empowerment in challenging environments: A case study from Balochistan. Retrieved from http ://pqdl.care.org/sii/SIILibrary/ Women\%E2\%80\%99s\%20 Empowerment\%20Pakistan\%20Women\%E2\%80\%99s\%20Empowerment\%20in\%20Challengin g\%20Environments\%20(Patterson)\%202005.pdf 
Purayidathil, J., \& Shejwal, B. R. (2005). Impact of television viewing on adolescent lives, cognitive processes and adjustment. Psychological Studies, 50(1), 90-97. Retrieved from http://smart.whad.org/dcwc-research-bulletin-vol-ix-issue-3-july-september-2005-index-4

Sethuraman, K., Lansdown, R., \& Sullivan, K. (2006). Women's empowerment and domestic violence: the role of sociocultural determinants in maternal and child undernutrition in tribal and rural communities in South India. Retrieved from http:/ /www .ncbi.nlm.nih.gov /pubmed /16786979

United Nations Population Information Network. (n.d.). Guidelines on Women's Empowerment. Retrieved from http://www.un.org/popin/unfpa/taskforce/guide/iatfwemp.gdl.html

Women in Agriculture: Meaning \&Concept. (n.d.). Retrieved from http://e courses online.iasri.res.in/ $\mathrm{mod} /$ page/view.php?id=119487

Zimmerman, A. \& Dahlberg, J. (2008). Sexual objectification of women in advertising. Journal of Advertising Research. 71-79. 